\title{
Terrabacter aerolatus sp. nov., isolated from an air sample
}

\author{
Hang-Yeon Weon, ${ }^{1}$ Peter Schumann, ${ }^{2}$ Reiner M. Kroppenstedt, ${ }^{2}$ \\ Byung-Yong Kim, ${ }^{3}$ Jaekyeong Song, ${ }^{3}$ Soon-Wo Kwon, ${ }^{3}$ Seung-Joo Go ${ }^{3}$ \\ and Erko Stackebrandt ${ }^{2}$
}

\begin{abstract}
Correspondence
Soon-Wo Kwon

swkwon@rda.go.kr
\end{abstract}

\author{
${ }^{1}$ Applied Microbiology Division, National Institute of Agricultural Science and Technology, Rural \\ Development Administration, Suwon 441-707, Republic of Korea
${ }^{2}$ DSMZ - Deutsche Sammlung von Mikroorganismen und Zellkulturen GmbH, Inhoffenstraße 7b, 38124 Braunschweig, Germany \\ ${ }^{3}$ KACC - Korean Agricultural Culture Collection, Microbial Genetics Division, National Institute of \\ Agricultural Biotechnology, Rural Development Administration, Suwon 441-707, Republic of Korea
}

\begin{abstract}
A Gram-positive, strictly aerobic, motile, rod- or coccoid-shaped bacterium, strain $5516 \mathrm{~J}-36^{\top}$, was isolated from an air sample from Jeju region, Korea, and its taxonomic position was investigated by a polyphasic approach. The organism grew optimally at $30{ }^{\circ} \mathrm{C}$ and $\mathrm{pH} 7.0-8.0$. Comparative 16S rRNA gene sequencing studies demonstrated that this strain was highly related phylogenetically to Terrabacter terrae PPLB ${ }^{\top}$ and Terrabacter tumescens DSM $20308^{\top}$, showing $98.9 \%$ sequence similarity to both strains. However, the DNA-DNA reassociation values between $5516 \mathrm{~J}-36^{\top}$ and the type strains of Terrabacter terrae and Terrabacter tumescens were low (51 and $48 \%$, respectively). The peptidoglycan type was $A 3 \gamma$, the predominant menaquinone was $\mathrm{MK}-8\left(\mathrm{H}_{4}\right)$, the polar lipids were phosphatidylethanolamine, diphosphatidylglycerol, phosphatidylinositol and an unidentified phosphoglycolipid and the wholecell sugars were glucose, ribose, rhamnose, xylose and galactose. Mycolic acids were absent.

The major fatty acids ( $>5 \%$ of total fatty acids) were iso- $C_{15: 0}$, iso- $C_{16: 0}$, iso- $C_{14: 0}$, iso- $C_{17: 0}$ and anteiso- $\mathrm{C}_{15: 0}$. The DNA G $+\mathrm{C}$ content was $71.7 \mathrm{~mol} \%$. On the basis of the above data, it is proposed that strain $5516 \mathrm{~J}-36^{\top}$ represents a novel species, Terrabacter aerolatus sp. nov. The type strain of Terrabacter aerolatus is $5516 \mathrm{~J}-36^{\top}\left(=\right.$ KACC $20556^{\top}=$ DSM $\left.18562^{\top}\right)$.
\end{abstract}

The genus Terrabacter, with the type species Terrabacter tumescens, was created by the transfer of Pimelobacter tumescens on the basis of phylogenetic and chemotaxonomic data (Collins et al., 1989). Recently, another species Terrabacter terrae was proposed for an isolate from soil in Spain (Montero-Barrientos et al., 2005). The genus was placed in the family Intrasporangiaceae and is characterized by $\mathrm{MK}-8\left(\mathrm{H}_{4}\right)$ as the predominant isoprenoid quinone, $\mathrm{A} 3 \gamma$ as the peptidoglycan type, iso- $\mathrm{C}_{15: 0}$ as the major fatty acid and high DNA G $+\mathrm{C}$ contents (71-73 mol\%).

Strain $5516 \mathrm{~J}-36^{\mathrm{T}}$ was isolated from an air sample from the Jeju region of Korea. The air sample was collected using an MAS-100 air sampler (Merck; single-stage multiple-hole impactor) which contained Petri dishes with R2A agar (BBL) amended with $200 \mu \mathrm{g}$ cycloheximide $\mathrm{ml}^{-1}$ (Sigma). After sampling, plates were incubated at $30{ }^{\circ} \mathrm{C}$ for 5 days, and strain 5516 $\mathrm{J}-36^{\mathrm{T}}$ was recovered. Terrabacter tumescens

The GenBank/EMBL/DDBJ accession number for the 16S rRNA gene sequence of strain $5516 \mathrm{~J}-36^{\top}$ is EF2 12039.
DSM $20308^{\mathrm{T}}$ and Terrabacter terrae CECT $3379^{\mathrm{T}}$ were used as reference strains. These strains were cultivated on R2A medium ( $\mathrm{pH} 7.0$; Difco) at $30{ }^{\circ} \mathrm{C}$ and maintained on $\mathrm{R} 2 \mathrm{~A}$ medium.

The 16S rRNA gene of the isolate was amplified by a PCR and sequenced directly using an ABI Prism 310 Genetic Analyzer (Applied Biosystems). Phylogenetic analysis was carried out using MEGA3 (Kumar et al., 2004) after multiple alignment of the sequences by CLUSTAL W (Thompson et al., 1994). Distances using distance options according to the Kimura two-parameter model (Kimura, 1983) and clustering using neighbour-joining were determined by using bootstrap values based on 1000 replicates. DNA-DNA hybridization was carried out as described by Seldin \& Dubnau (1985). Probe labelling was conducted by using the non-radioactive DIG High Prime DNA labelling and detection starter kit II (Roche Molecular Biochemicals). Reassociation was conducted at $65{ }^{\circ} \mathrm{C}$. The hybridized DNA was visualized using the DIG luminescent detection kit (Roche). DNA-DNA relatedness was quantified by using a densitometer (Bio-Rad). 
For strain $5516 \mathrm{~J}-36^{\mathrm{T}}, 1400 \mathrm{bp}$ of the $16 \mathrm{~S}$ rRNA gene sequence was determined. Comparative $16 \mathrm{~S}$ rRNA gene sequence analysis showed that strain $5516 \mathrm{~J}-36^{\mathrm{T}}$ was most closely related to members of the genus Terrabacter. In a phylogenetic tree based on the neighbour-joining algorithm, strain $5516 \mathrm{~J}-36^{\mathrm{T}}$ joined the clade comprising Terrabacter species at a bootstrap confidence value of $100 \%$ (Fig. 1). Strain 5516J-36 ${ }^{\mathrm{T}}$ exhibited $16 \mathrm{~S}$ rRNA gene sequence similarity values of $98.9 \%$ to both Terrabacter terrae PPLB $^{\mathrm{T}}$ and Terrabacter tumescens DSM $20308^{\mathrm{T}}$. It showed 97.4 and $96.9 \%$ sequence similarity, respectively, to Terracoccus luteus DSM $44267^{\mathrm{T}}$ and Intrasporangium calvum DSM $43043^{\mathrm{T}}$. DNA-DNA relatedness data demonstrated that strain $5516 \mathrm{~J}-36^{\mathrm{T}}$ represents a genomic species that is different from recognized Terrabacter species (Wayne et al., 1987). DNA-DNA relatedness values between strain $5516 \mathrm{~J}-36^{\mathrm{T}}$ and Terrabacter tumescens DSM $20308^{\mathrm{T}}$, Terrabacter terrae CECT $3379^{\mathrm{T}}$ and Terracoccus luteus DSM $44267^{\mathrm{T}}$ were respectively 51, 48 and $32 \%$.

Cell morphology was examined by phase-contrast microscopy (AXIO; Zeiss). The isolate was tested for a number of key characteristics, such as Gram staining, catalase, oxidase and hydrolysis of casein, DNA, hypoxanthine, gelatin, starch, Tween 80 and xanthine, by using standard procedures (Smibert \& Krieg, 1994). Growth was assessed at $5,10,20,25,30,35$ and $40{ }^{\circ} \mathrm{C}$, at pH $4-10$ (increments of $1 \mathrm{pH}$ unit) and at $0,1,3,5,7$ and $10 \% \mathrm{NaCl}$. Hydrolysis of CM-cellulose (Sigma) $(0.1 \%)$, chitin from crab shells $(1 \%, \mathrm{w} / \mathrm{v})$, pectin $(0.5 \%, \mathrm{w} / \mathrm{v})$ and tyrosine $(0.5 \%, \mathrm{w} / \mathrm{v})$ was checked. Motility was examined on 1/10-strength R2A medium. Anaerobic growth was checked using a BBL anaerobic jar (Becton Dickinson). Other physiological properties and enzyme activities were tested using the API 20NE, API ID 32GN and API ZYM systems (bioMérieux). The results of API 20NE and API ID 32GN were recorded after 5 days incubation.

Strain $5516 \mathrm{~J}-36^{\mathrm{T}}$ formed visible colonies on R2A agar after $48 \mathrm{~h}$ at $28{ }^{\circ} \mathrm{C}$. The strain grew on R2A, nutrient agar (Difco) and tryptic soy agar (TSA; Difco), but did not grow on MacConkey agar (Difco). The colonies were white, convex and round. Cells were strictly aerobic, Grampositive, motile, catalase-positive and oxidase-negative. Cells are cocci (diameter $0.9-1.0 \mu \mathrm{m}$ ) that occur in pairs, or rods $(0.9 \times 1.5-3.5 \mu \mathrm{m})$. The physiological and biochemical characteristics are summarized in Table 1.

Biomass for chemotaxonomic studies was grown in shake flasks of R2A broth for 4 days at $28{ }^{\circ} \mathrm{C}$, checked for purity, harvested by centrifugation and freeze-dried. The peptidoglycan was analysed as described by Schleifer \& Kandler (1972). The phospholipids and menaquinones were analysed by the method of Minnikin et al. (1984). Sugar analysis of whole cells and mycolic acid determinations were carried out as described by Staneck \& Roberts (1974) and Minnikin et al. (1975), respectively. For fatty acid methyl ester analysis, cell mass of strain $5516 \mathrm{~J}-36^{\mathrm{T}}$ was harvested from TSA plates after incubation for 3 days at $28{ }^{\circ} \mathrm{C}$. Analyses of the whole-cell fatty acid pattern followed described methods using the MIDI system (Microbial ID, Inc.) (Kroppenstedt, 1985; Sasser, 1990). The G+C content of the DNA was determined according to Mesbah et al. (1989) using a reversed-phase column (Supelcosil LC-18S; Supelco).

From quantitative analysis of the peptidoglycan amino acids by gas chromatography, strain $5516 \mathrm{~J}-36^{\mathrm{T}}$ contained glycine, alanine, glutamic acid and LL-diaminopimelic acid in an approximate molar ratio of $4.0: 1.8: 1.0: 1.0$. From the two-dimensional TLC pattern (not shown) of peptides in the partial peptidoglycan hydrolysate, strain 5516 J-36 ${ }^{\mathrm{T}}$ showed peptidoglycan type A3 $\gamma$ as described by Schleifer \& Kandler (1972) (type A41.1 according to http://www. dsmz.de/species/murein.htm). The predominant menaquinone was MK- $8\left(\mathrm{H}_{4}\right)$. The polar lipids phosphatidylethanolamine, diphosphatidylglycerol, phosphatidylinositol and a phosphoglycolipid of unknown structure were detected. The peptidoglycan structure, isoprenoid quinone and polar lipids of strain $5516 \mathrm{~J}-36^{\mathrm{T}}$ were congruent with those of the two recognized species of the genus Terrabacter. The predominant fatty acids were iso- $\mathrm{C}_{15: 0}$ $(49.0 \%)$, iso- $\mathrm{C}_{16: 0}(14.5 \%)$, iso- $\mathrm{C}_{14: 0}(7.9 \%)$, iso- $\mathrm{C}_{17: 0}$ $(5.8 \%)$ and anteiso- $\mathrm{C}_{15: 0}(5.2 \%)$ (Table 2$)$. The fatty acid profile of strain $5516 \mathrm{~J}-36^{\mathrm{T}}$ was similar to that of Terrabacter terrae CECT $3379^{\mathrm{T}}$, which was considerably different from that of Terrabacter tumescens DSM $20308^{\mathrm{T}}$ (Montero-Barrientos et al., 2005). The whole-cell sugar profile contained glucose, ribose, rhamnose, xylose and galactose (in decreasing order of abundance). Mycolic

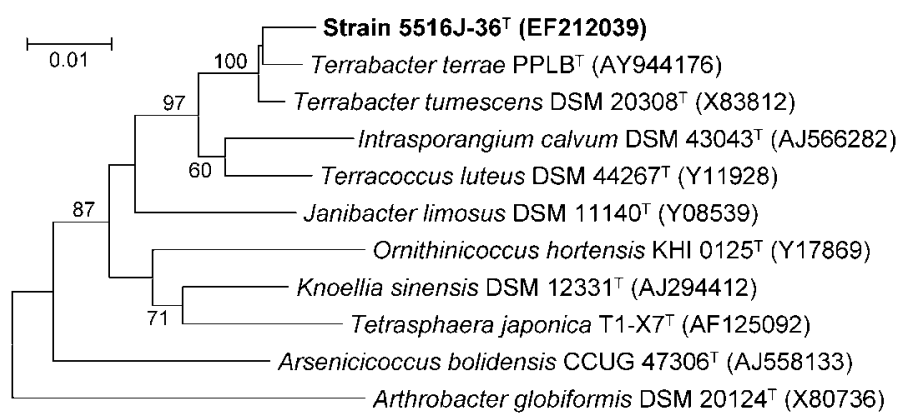

Fig. 1. $16 \mathrm{~S}$ rRNA gene sequence-based dendrogram obtained by distance matrix (neighbour-joining) analysis showing the position of strain $5516 \mathrm{~J}-36^{\top}$. Numbers at nodes indicate levels of bootstrap support based on a neighbour-joining analysis of 1000 resampled datasets. Bootstrap values below $50 \%$ are not indicated. Bar, 0.01 substitutions per position. 
Table 1. Differential characteristics between strain $5516 \mathrm{~J}-36^{\top}$ and type strains of Terrabacter species

Strains: 1, 5516 $\mathrm{J}-36^{\mathrm{T}} ; 2$, Terrabacter tumescens DSM $20308^{\mathrm{T}}$; 3 , Terrabacter terrae CECT $3379^{\mathrm{T}}$. Data were obtained in this study unless indicated. According to API 20NE and API ZYM strips, all strains are positive for aesculin hydrolysis, gelatin hydrolysis and $\beta$ galactosidase, esterase (C4), esterase lipase (C8), leucine arylamidase, acid phosphatase, naphthol-AS-BI-phosphohydrolase, $\alpha$-galactosidase and $\alpha$-glucosidase activities. All strains are negative for indole production, glucose fermentation and arginine dihydrolase, urease, alkaline phosphatase, cystine arylamidase, trypsin, $\alpha$-chymotrypsin, $\beta$ glucuronidase, $N$-acetyl- $\beta$-glucosaminidase and $\alpha$-fucosidase activities. According to API $20 \mathrm{NE}$ and API ID32GN strips, all strains assimilate D-glucose, D-mannose, $N$-acetylglucosamine, maltose, potassium gluconate, malic acid, inositol, sucrose, sodium malonate, sodium acetate, L-alanine, glycogen, propionic acid, valeric acid, Lhistidine and 3-hydroxybutyric acid. None of the strains assimilate capric acid, trisodium citrate, phenylacetic acid, L-rhamnose, itaconic acid, suberic acid, potassium 5-ketogluconate, salicin, L-fucose, potassium 2-ketogluconate or 4-hydroxybenzoic acid. +, Positive; $(+)$, weakly positive; - , negative.

\begin{tabular}{|c|c|c|c|}
\hline Characteristic & 1 & 2 & 3 \\
\hline Cell shape & Rod/coccus & Rod/coccus ${ }^{*}$ & Long rods ${ }^{\star}$ \\
\hline Colony colour & White & White/grey ${ }^{*}$ & Yellow $^{*}$ \\
\hline Motility & + & $(+)^{*}$ & $-^{*}$ \\
\hline Growth on $7 \% \mathrm{NaCl}$ & - & $-{ }^{\star}$ & $+^{*}$ \\
\hline Nitrate reduction & + & + & - \\
\hline \multicolumn{4}{|l|}{ Assimilation of: } \\
\hline L-Arabinose & - & + & + \\
\hline D-Mannitol & + & + & - \\
\hline Adipic acid & $(+)$ & $(+)$ & - \\
\hline D-Ribose & - & - & + \\
\hline Lactic acid & - & - & + \\
\hline $\begin{array}{l}\text { 3-Hydroxybenzoic } \\
\text { acid }\end{array}$ & - & + & - \\
\hline L-Serine & - & - & + \\
\hline D-Melibiose & + & + & - \\
\hline D-Sorbitol & + & + & - \\
\hline L-Proline & - & + & - \\
\hline \multicolumn{4}{|l|}{ Enzyme activities } \\
\hline Lipase (C14) & + & - & - \\
\hline Valine arylamidase & + & - & - \\
\hline$\beta$-Glucosidase & $(+)$ & - & - \\
\hline$\alpha$-Mannosidase & $(+)$ & - & - \\
\hline $\begin{array}{l}\text { DNA G }+ \text { C content } \\
(\mathrm{mol} \%)\end{array}$ & 71.7 & 73 & 71 \\
\hline
\end{tabular}

${ }^{\star}$ Data from Montero-Barrientos et al. (2005).

acids were absent. The DNA G $+C$ content of strain 5516J$36^{\mathrm{T}}$ was $71.7 \mathrm{~mol} \%$.

On the basis of the data presented, strain $5516 \mathrm{~J}-36^{\mathrm{T}}$ should therefore be placed in the genus Terrabacter within a novel species, for which the name Terrabacter aerolatus sp. nov. is proposed.
Table 2. Cellular fatty acid compositions of strain $5516 \mathrm{~J}-36^{\top}$ and type strains of Terrabacter species

Strains: 1, 5516J-36 $6^{\mathrm{T}} ; 2$, Terrabacter tumescens DSM 20308 ${ }^{\mathrm{T}}$; 3, Terrabacter terrae CECT $3379^{\mathrm{T}}$. All strains were grown for 2 days on TSA. Values are percentages of total fatty acids; fatty acids that represented $<0.5 \%$ in all strains are omitted. - , Not detected.

\begin{tabular}{|c|c|c|c|}
\hline Fatty acid & 1 & 2 & 3 \\
\hline iso- $\mathrm{C}_{13: 0}$ & 0.7 & 0.2 & 0.3 \\
\hline $\mathrm{C}_{14: 0}$ & 0.6 & 5.8 & 1.8 \\
\hline iso- $\mathrm{C}_{14: 0}$ & 7.9 & 5.5 & 3.1 \\
\hline iso- $\mathrm{C}_{15: 0}$ & 49.0 & 17.2 & 32.0 \\
\hline anteiso- $\mathrm{C}_{15: 0}$ & 5.2 & 6.5 & 19.6 \\
\hline $\mathrm{C}_{16: 0}$ & 3.3 & 11.5 & 5.6 \\
\hline $\mathrm{C}_{16: 0}$ 10-methyl & - & 1.6 & - \\
\hline iso- $\mathrm{C}_{16: 0}$ & 14.5 & 6.1 & 5.2 \\
\hline iso- $\mathrm{C}_{16: 1} \mathrm{H}$ & 0.5 & 0.6 & 0.8 \\
\hline $\mathrm{C}_{17: 0}$ & 1.4 & 5.5 & 1.6 \\
\hline $\mathrm{C}_{17: 0}$ 10-methyl & 0.1 & 0.6 & - \\
\hline iso- $\mathrm{C}_{17: 0}$ & 5.8 & 0.9 & 2.0 \\
\hline anteiso- $\mathrm{C}_{17: 0}$ & 3.1 & 2.0 & 7.2 \\
\hline $\mathrm{C}_{17: 1} \omega 8 c$ & 0.8 & 7.3 & 2.4 \\
\hline iso- $\mathrm{C}_{17: 1} \omega 9 c$ & 0.9 & - & 1.6 \\
\hline anteiso- $\mathrm{C}_{17: 1} \omega 9 c$ & 0.3 & - & 2.3 \\
\hline $\mathrm{C}_{18: 0}$ & 3.2 & 5.4 & 2.3 \\
\hline iso- $\mathrm{C}_{18: 0}$ & 0.8 & 0.3 & - \\
\hline $\mathrm{C}_{18: 1} \omega 9 \mathrm{c}$ & 0.9 & 13.1 & 4.3 \\
\hline $\mathrm{C}_{18: 1} \omega 7 c$ & - & 0.5 & - \\
\hline Summed feature $3^{*}$ & 1.0 & 7.1 & 7.1 \\
\hline Summed feature $6^{*}$ & - & 0.9 & - \\
\hline
\end{tabular}

${ }^{*}$ Summed feature 3 comprises iso- $\mathrm{C}_{15: 0}$ 2-OH and/or $\mathrm{C}_{16: 1} \omega 7 c$; summed feature 6 comprises $\mathrm{C}_{19: 1} \omega 11 c$ and/or $\mathrm{C}_{19: 1} \omega 9 c$.

\section{Description of Terrabacter aerolatus sp. nov.}

Terrabacter aerolatus (ae.ro.la'tus. Gr. n. aer air; L. part. adj. latus carried; N.L. masc. part. adj. aerolatus airborne).

Cells are strictly aerobic, Gram-positive, motile rods or cocci $(0.9-1.0 \times 1.0-3.5 \mu \mathrm{m})$, catalase-positive and oxidase-negative. Colonies are white, convex and round. Optimal temperature for growth is $30{ }^{\circ} \mathrm{C}$. Growth occurs in the range $5-35{ }^{\circ} \mathrm{C}$. Optimal $\mathrm{pH}$ for growth is between 7.0 and 8.0; growth occurs in the range $\mathrm{pH} 4-9$. Growth occurs in the presence of $0-5 \%(\mathrm{w} / \mathrm{v}) \mathrm{NaCl}$. Casein, starch, tyrosine and Tween 80 are hydrolysed, but chitin, CMcellulose, DNA, pectin, hypoxanthine and xanthine are not. LL-Diaminopimelic acid-containing peptidoglycan A3 $\gamma$ has three glycine residues as the interpeptide bridge. Whole-cell sugars are glucose, ribose, rhamnose, xylose and galactose (in decreasing order of abundance). Mycolic acids are absent. The predominant menaquinone is $\mathrm{MK}-8\left(\mathrm{H}_{4}\right)$. The major fatty acids ( $>5 \%$ of total fatty acids) are iso- $\mathrm{C}_{15: 0}$ $(49.0 \%)$, iso- $\mathrm{C}_{16: 0}(14.5 \%)$, iso- $\mathrm{C}_{14: 0}(7.9 \%)$, iso- $\mathrm{C}_{17: 0}$ $(5.8 \%)$ and anteiso- $\mathrm{C}_{15: 0}(5.2 \%)$. The major polar lipids are phosphatidylethanolamine, diphosphatidylglycerol, 
phosphatidylinositol and an unidentified phosphoglycolipid. The DNA $\mathrm{G}+\mathrm{C}$ content of the type strain is $71.7 \mathrm{~mol} \%$.

The type strain, 5516J-36 ${ }^{\mathrm{T}}$ (=KACC $20556^{\mathrm{T}}=\mathrm{DSM}$ $\left.18562^{\mathrm{T}}\right)$, was isolated from an air sample in Jeju, Korea.

\section{Acknowledgements}

This study was supported by the National Institute of Agricultural Biotechnology (NIAB grant no. 06-4-11-19-1), Rural Development Administration, Republic of Korea.

\section{References}

Collins, M. D., Dorsch, M. \& Stackebrandt, E. (1989). Transfer of Pimelobacter tumescens to Terrabacter gen. nov. as Terrabacter tumescens comb. nov. and of Pimelobacter jensenii to Nocardioides jensenii comb. nov. Int J Syst Bacteriol 39, 1-6.

Kimura, M. (1983). The Neutral Theory of Molecular Evolution. Cambridge: Cambridge University Press.

Kroppenstedt, R. M. (1985). Fatty acid and menaquinone analysis of actinomycetes and related organisms. In Chemical Methods in Bacterial Systematics (SAB Technical Series no. 20), pp. 173-199. Edited by M. Goodfellow \& D. E. Minnikin. London: Academic Press.

Kumar, S., Tamura, K. \& Nei, M. (2004). MEGA3: integrated software for molecular evolutionary genetics analysis and sequence alignment. Brief Bioinform 5, 150-163.

Mesbah, M., Premachandran, U. \& Whitman, W. B. (1989). Precise measurement of the $\mathrm{G}+\mathrm{C}$ content of deoxyribonucleic acid by highperformance liquid chromatography. Int J Syst Bacteriol 39, 159-167.

Minnikin, D. E., Alshamaony, L. \& Goodfellow, M. (1975). Differentiation of Mycobacterium, Nocardia, and related taxa by thin-layer chromatographic analysis of whole-organism methanolysates. J Gen Microbiol 88, 200-204.

Minnikin, D. E., O'Donnell, A. G., Goodfellow, M., Alderson, G., Athalye, M., Schaal, K. \& Parlett, J. H. (1984). An integrated procedure for the extraction of bacterial isoprenoid quinones and polar lipids. J Microbiol Methods 2, 233-241.

Montero-Barrientos, M., Rivas, R., Velázquez, E., Monte, E. \& Roig, M. G. (2005). Terrabacter terrae sp. nov., a novel actinomycete isolated from soil in Spain. Int J Syst Evol Microbiol 55, 2491-2495.

Sasser, M. (1990). Identification of bacteria by gas chromatography of cellular fatty acids, MIDI Technical Note 101. Newark, DE: MIDI Inc.

Schleifer, K. H. \& Kandler, O. (1972). Peptidoglycan types of bacterial cell walls and their taxonomic implications. Bacteriol Rev 36, 407-477.

Seldin, L. \& Dubnau, D. (1985). Deoxyribonucleic acid homology among Bacillus polymyxa, Bacillus macerans, Bacillus azotofixans, and other nitrogen-fixing Bacillus strains. Int J Syst Bacteriol 35, 151-154.

Smibert, R. M. \& Krieg, N. R. (1994). Phenotypic characterization. In Methods for General and Molecular Bacteriology, pp. 607-654. Edited by P. Gerhardt, R. G. E. Murray, W. A. Wood \& N. R. Krieg. Washington, DC: American Society for Microbiology.

Staneck, J. L. \& Roberts, G. D. (1974). Simplified approach to identification of aerobic actinomycetes by thin-layer chromatography. Appl Microbiol 28, 226-231.

Thompson, J. D., Higgins, D. G. \& Gibson, T. J. (1994). ClustaL W: improving the sensitivity of progressive multiple sequence alignment through sequence weighting, position-specific gap penalties and weight matrix choice. Nucleic Acids Res 22, 4673-4680.

Wayne, L. G., Brenner, D. J., Colwell, R. R., Grimont, P. A. D., Kandler, O., Krichevsky, M. I., Moore, L. H., Moore, W. E. C., Murray, R. G. E. \& other authors (1987). International Committee on Systematic Bacteriology. Report of the ad hoc committee on reconciliation of approaches to bacterial systematics. Int J Syst Bacteriol 37, 463-464. 